\title{
Insights from Water Quality of High Andean Springs for Human Consumption in Peru
}

\author{
David Choque-Quispe ${ }^{1, *} \mathbb{*}$, Sandro Froehner ${ }^{2}$, Carlos A. Ligarda-Samanez $\left.{ }^{1} \mathbb{(}\right)$, Betsy S. Ramos-Pacheco ${ }^{1}$, \\ Diego Elio Peralta-Guevara ${ }^{1}$, Henry Palomino-Rincón ${ }^{3}$, Yudith Choque-Quispe ${ }^{4}$, Aydeé M. Solano-Reynoso ${ }^{5}$, \\ Gloria I. Barboza-Palomino ${ }^{6}$, Fredy Taipe-Pardo ${ }^{3}$ and L. Magali Zamalloa-Puma ${ }^{7}$
}

1 Water Analysis and Control Research Laboratory, Universidad Nacional José María Arguedas, Andahuaylas 03701, Peru; caligarda@unajma.edu.pe (C.A.L.-S.); bsramos@unajma.edu.pe (B.S.R.-P.); diepltagvra@gmail.com (D.E.P.-G.)

2 Department of Environmental Engineering, Universidade Federal do Parana (UFPR), Curitiba 80010, Brazil; froehner@ufpr.br

3 Agroindustrial Engineering, Universidad Nacional José María Arguedas, Andahuaylas 03701, Peru; hpalomino@unajma.edu.pe (H.P.-R.); ftaipe@unajma.edu.pe (F.T.-P.)

4 Environmental Engineering, Universidad Nacional José María Arguedas, Andahuaylas 03701, Peru; yuditchoque@gmail.com

5 Department of Environmental Engineering, Universidad Tecnológica de los Andes, Apurímac 03000, Peru; ayma_21@hotmail.com

Citation: Choque-Quispe, D.; Froehner, S.; Ligarda-Samanez, C.A.; Ramos-Pacheco, B.S.; Peralta-Guevara, D.E.; Palomino-Rincón, H.; Choque-Quispe, Y.; Solano-Reynoso, A.M.; Barboza-Palomino, G.I.; Taipe-Pardo, F.; et al. Insights from Water Quality of High Andean Springs for Human Consumption in Peru. Water 2021, 13, 2650. https:// doi.org/10.3390/w13192650

Academic Editor: George Arhonditsis

Received: 4 July 2021

Accepted: 22 September 2021

Published: 26 September 2021

Publisher's Note: MDPI stays neutral with regard to jurisdictional claims in published maps and institutional affiliations.

Copyright: (c) 2021 by the authors. Licensee MDPI, Basel, Switzerland. This article is an open access article distributed under the terms and conditions of the Creative Commons Attribution (CC BY) license (https:// creativecommons.org/licenses/by/ $4.0 /)$.
Department of Chemical Engineering, Universidad Nacional de San Cristobal de Huamanga, Ayacucho 05000, Peru; gibpbarboza@hotmail.com

7 Research Group for the Development of Films Based on Biological Materials, Universidad Nacional de San Antonio Abad del Cusco, Cusco 08000, Peru; lourdes.zamalloa@unsaac.edu.pe

* Correspondence: dchoque@unajma.edu.pe

Abstract: The headwaters of the high Andean basin in Peru accumulate water from the mist, rain, snow, and hail, and it is transported superficially and underground to low-lying areas, mostly used for drinkable purposes. The natural water in these areas might be altered due to legal and illegal mining extraction. The aim of the study was to evaluate the water quality for human consumption. Seventeen water samples were examined from Andahuaylas (A), San Jerónimo (S), Talavera (T), and Chiara $(\mathrm{CH})$ districts located between 2813 and $4004 \mathrm{~m}$ altitude in the Andes. We used physicochemical, microbiological, and metal parameters, and the results were compared to permissible levels established by the WHO and ECA-Peru to examine samples collected in the dry and rainy seasons in 2019. Application of principal component analysis (PCA) identified areas and conditioning parameters. Extractive mining activity influences the quality of springs due to the presence of metals, especially antimony $(\mathrm{Sb})$, arsenic $(\mathrm{As})$, cadmium $(\mathrm{Cd})$, and lead $(\mathrm{Pb})$, values of which are higher than values permissible for human consumption, being higher in the dry season $(p<0.05)$. In addition, the presence of cations and particulate matter affects physico-chemical parameters, for example turbidity. PCA showed that parameters for water characterization are season-independent, and water quality in the springs would be conditioned by the presence of metals, especially in Andahuaylas and Talavera zones, as well as the parameters that are associated with dissolved solids in the water (turbidity and fluorides). A frequent monitoring program of springs and groundwater is recommended, with the purpose to protect water from contamination and guarantee safe water availability in low-lying and urbanized areas.

Keywords: high Andean spring; dry and rainy season; extractive mining; sources of consumption

\section{Introduction}

Water is essential for the three dimensions of sustainable development: social, economic, and environmental [1-3]. The Andes concentrates more than $99 \%$ of the world's tropical glaciers, and the highest percentage of these glaciers are housed in Peru (71\%), 
followed by Bolivia (20\%), Ecuador (4\%), and Colombia-Venezuela (4\%) [4]. Water in the high Andean areas is distributed in fragile ecosystems $[5,6]$ due to the complex interaction between climate and geomorphology, which can be altered by anthropogenic activities [7].

Many developed countries have taken into account that not only the quantity of water but also its quality is essential for the development of a healthy society; therefore, different water management and quality policies have been designed [8,9], while developing countries make efforts through their governments to meet the basic conditions of water supply.

The high Andean areas of Peru are characterized by being the headwaters of basins, the place where the water is born in its natural form from the thawing of the snow-capped mountains and springs, flowing from $4500 \mathrm{~m}$ altitude, descending to the plain by underground infiltration, and gushing through springs. In the same way, these headwaters have metallic mining deposits, where copper, iron, gold, and silver are extracted, which are exploited in both a legal and illegal way. These mining activities release large amounts of metals from the removed soils, infiltrating by runoff due to geomorphology and rainfall $[10,11]$, reaching the water sources for human consumption. The presence of heavy metals in water for human consumption may be a health risk to the population due to bioaccumulation, especially of arsenic, chromium, aluminum, nickel, and lead, among others $[2,12,13]$.

Similarly, other anthropic activities such as agriculture and animal husbandry generate wastewater whose polluting components infiltrate into the underground streams of water for human consumption, which alter their quality $[14,15]$. Therefore, monitoring physical, chemical, biological, and microbiological parameters will allow attending to water quality for human consumption [16,17]. This is established through water quality standards (ECA) in Peru [18].

Many places in Peru, especially the urban and rural population, consume piped water from different water sources or springs, and it is transported and stored in reservoirs where calcium hypochlorite solution is added as a disinfectant. Then, it is distributed through the piping network to homes.

Water sources in rural and high Andean areas of Peru are managed by the Administrative Board of Sanitation Services (Junta Administradora de Servicios de SaneamientoJASS), who distributes water for human consumption, irrigation, and other communal and private activities within their jurisdiction. These boards are protected by Peruvian legislation, but they do not have scope in terms of water quality. Only the health centers and municipalities analyze the level of residual chlorine, and that is the reason why the compositional status of water for human consumption is unknown [19-21].

In this sense, the neighboring populations are influenced by metallurgical mining activities conditioning the water quality in the different sources for human consumption. This paper evaluates the insights of the water quality of different high Andean springs in the dry and rainy seasons, where the main objectives are to: (1) know the physical, chemical, and microbiological characteristics of the water, (2) determine the level of the metals, and (3) identify relevant water quality parameters through principal component analysis (PCA).

\section{Materials and Methods}

\subsection{Description of the Study Area}

The study area includes Andahuaylas, Talavera, San Jerónimo, and Chiara districts, which are located between 2800 to $4000 \mathrm{~m}$ altitude in the province of Andahuaylas, Peru (Figure 1). The study was conducted during the dry and rainy season in 2019, in the Chumbao river micro-basin, with a Cwb climate according to Köppen (temperate with dry winters), with seasons characterized by intense rainfall between October and April, from 500 to $1000 \mathrm{~mm}$ /year (Figure 2), with a temperature between 5 and $23^{\circ} \mathrm{C}$, and an average relative humidity of $55 \%$. 


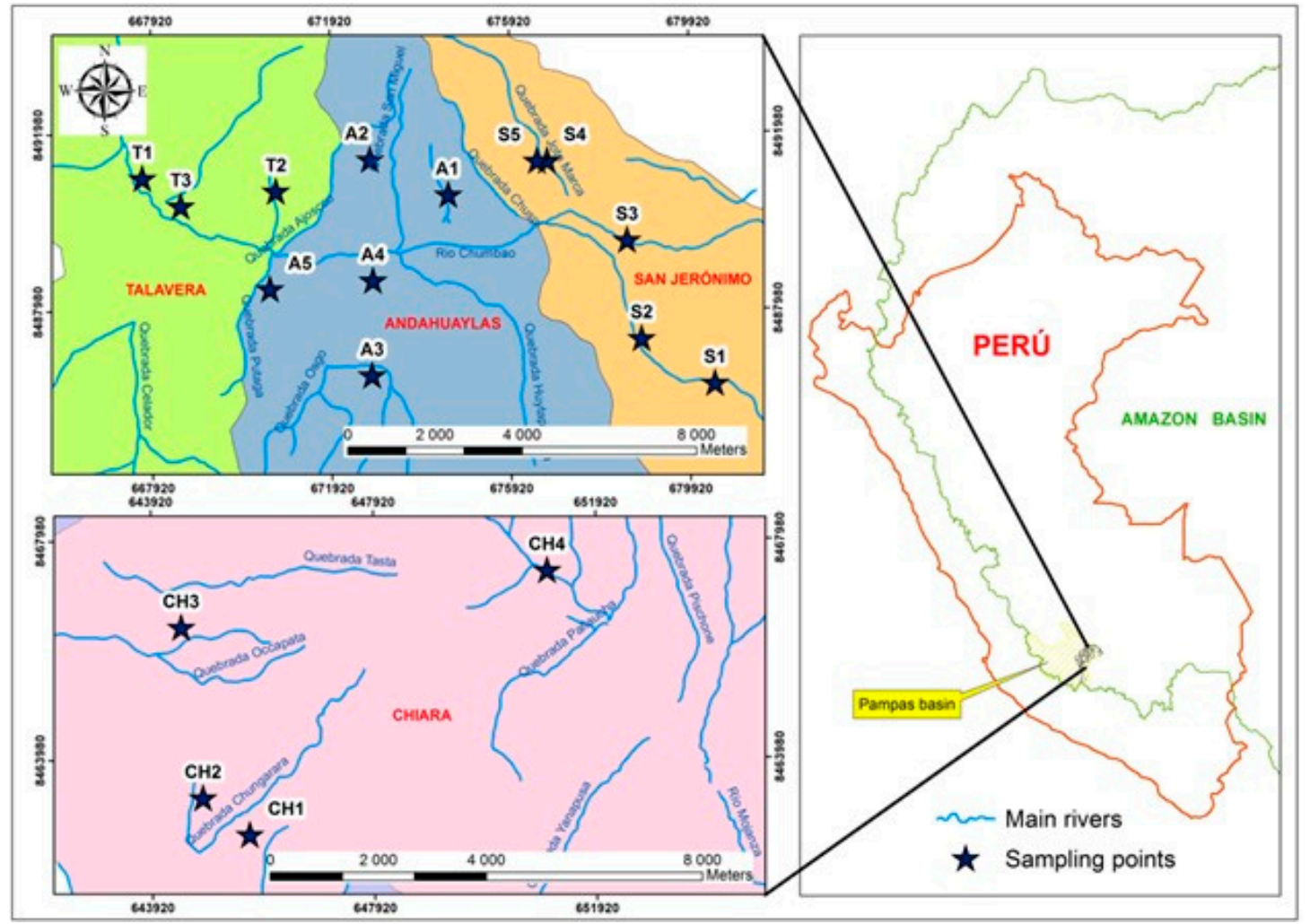

Figure 1. Distribution of sampling points in the study areas.

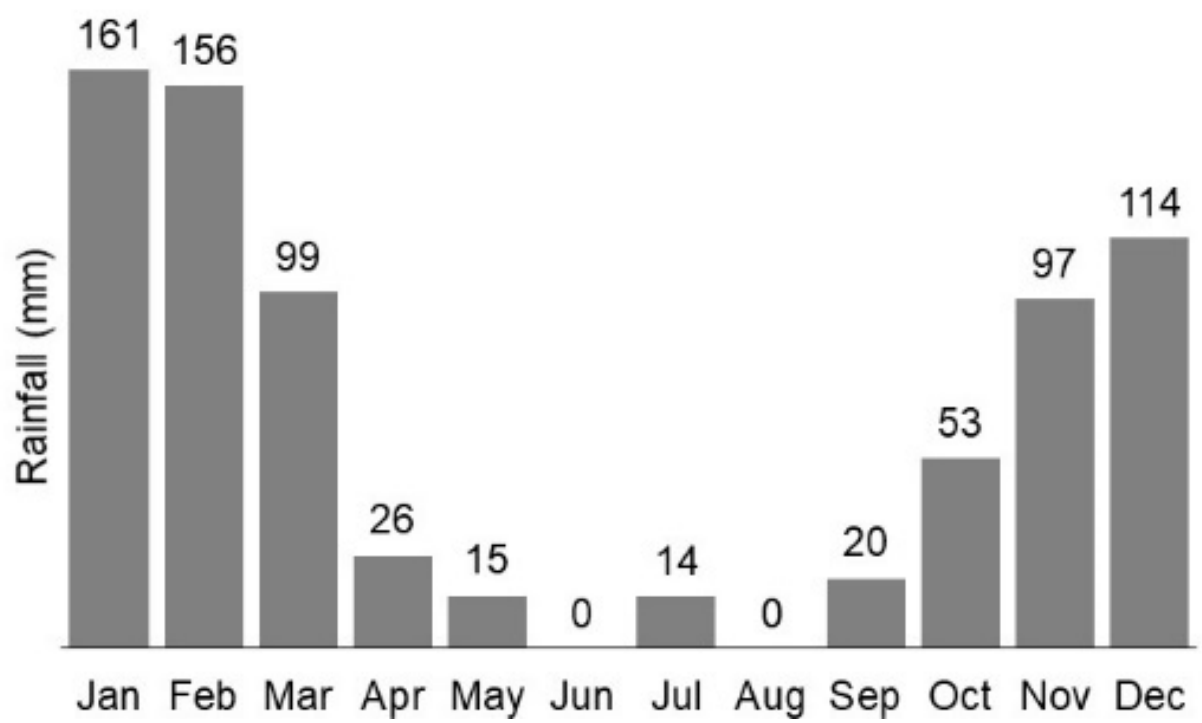

Figure 2. Precipitation between January and December 2019.

The inhabitants in the study areas are mainly engaged in agricultural and livestock activities, being approximately $20 \%$ agricultural areas, with potato and corn as the main crops. Additionally, the extractive metallurgical mining is both legal and illegal.

\subsection{Sampling Points}

Water sources (springs) were identified, which supply to the urban and rural areas of the districts of Andahuaylas, San Jerónimo, Talavera, and Chiara. Their coordinates are shown in Table 1, and permission for sampling was requested from representatives of JASS. 
Table 1. Sampling points' description.

\begin{tabular}{|c|c|c|c|c|c|c|}
\hline \multirow{2}{*}{ District } & & \multirow{2}{*}{ Water Source } & \multicolumn{2}{|c|}{ Coordinates } & \multirow{2}{*}{ Altitude (m) } & \multirow{2}{*}{ Zone } \\
\hline & & & $\mathbf{S}$ & $\mathbf{W}$ & & \\
\hline Andahuaylas & A1 & Lambrasccata-Urpaypuquio & $13^{\circ} 38^{\prime} 53.9^{\prime \prime}$ & $73^{\circ} 23^{\prime} 10.7^{\prime \prime}$ & 3120 & peri-urban \\
\hline Andahuaylas & A2 & Ccarancaylla & $13^{\circ} 38^{\prime} 28.0^{\prime \prime}$ & $73^{\circ} 24^{\prime} 08.9^{\prime \prime}$ & 3270 & peri-urban \\
\hline Andahuaylas & A3 & Pausihuaycco & $13^{\circ} 41^{\prime} 07.0^{\prime \prime}$ & $73^{\circ} 24^{\prime} 07.2^{\prime \prime}$ & 3100 & peri-urban \\
\hline Andahuaylas & A4 & Choccepuquio & $13^{\circ} 39^{\prime} 57.1^{\prime \prime}$ & $73^{\circ} 24^{\prime} 06.6^{\prime \prime}$ & 2872 & urban \\
\hline Andahuaylas & A5 & Pochccota & $13^{\circ} 41^{\prime} 12.3^{\prime \prime}$ & $73^{\circ} 19^{\prime} 52.4^{\prime \prime}$ & 3240 & peri-urban \\
\hline San Jerónimo & S1 & Totoral-Suylluacca & $13^{\circ} 40^{\prime} 39.4^{\prime \prime}$ & $73^{\circ} 20^{\prime} 47.0^{\prime \prime}$ & 3102 & urban \\
\hline San Jerónimo & $\mathrm{S} 2$ & Chocolinas & $13^{\circ} 39^{\prime} 27.0^{\prime \prime}$ & $73^{\circ} 20^{\prime} 57.9^{\prime \prime}$ & 3023 & urban \\
\hline San Jerónimo & S3 & Chaccrapata-Huasipara & $13^{\circ} 38^{\prime} 28.7^{\prime \prime}$ & $73^{\circ} 21^{\prime} 57.2^{\prime \prime}$ & 3146 & peri-urban \\
\hline San Jerónimo & S4 & Ccotamarca & $13^{\circ} 38^{\prime} 28.8^{\prime \prime}$ & $73^{\circ} 22^{\prime} 04.9^{\prime \prime}$ & 3178 & peri-urban \\
\hline Talavera & $\mathrm{T} 1$ & Chihuampata & $13^{\circ} 38^{\prime} 42.3^{\prime \prime}$ & $73^{\circ} 26^{\prime} 57.9^{\prime \prime}$ & 2805 & urban \\
\hline Talavera & $\mathrm{T} 2$ & Pachapuquio-Virgen del Carmen & $13^{\circ} 38^{\prime} 51.6^{\prime \prime}$ & $73^{\circ} 25^{\prime} 18.8^{\prime \prime}$ & 2922 & urban \\
\hline Talavera & $\mathrm{T} 3$ & $\begin{array}{lll}1 & \text { Aranjuez }\end{array}$ & $13^{\circ} 40^{\prime} 03.6^{\prime \prime}$ & $73^{\circ} 25^{\prime} 23.0^{\prime \prime}$ & 2865 & urban \\
\hline Talavera & $\mathrm{T} 4$ & Santa Rosa & $13^{\circ} 39^{\prime} 02.6^{\prime \prime}$ & $73^{\circ} 26^{\prime} 29.3^{\prime \prime}$ & 2813 & urban \\
\hline Chiara & $\mathrm{CH} 1$ & C.P. Chiara & $13^{\circ} 54^{\prime} 10.1^{\prime \prime}$ & $73^{\circ} 39^{\prime} 06.3^{\prime \prime}$ & 3190 & rural \\
\hline Chiara & $\mathrm{CH} 2$ & C.P. Chiara & $13^{\circ} 53^{\prime} 48.3^{\prime \prime}$ & $73^{\circ} 39^{\prime} 34.4^{\prime \prime}$ & 3170 & rural \\
\hline Chiara & $\mathrm{CH} 3$ & C.P. Chiara & $13^{\circ} 52^{\prime} 06.9^{\prime \prime}$ & $73^{\circ} 39^{\prime} 47.5^{\prime \prime}$ & 3405 & rural \\
\hline Chiara & $\mathrm{CH} 4$ & C.P. Chiara & $13^{\circ} 51^{\prime} 32.6^{\prime \prime}$ & $73^{\circ} 36^{\prime} 08.2^{\prime \prime}$ & 4004 & rural \\
\hline
\end{tabular}

\subsection{Determination of Chemical and Physico-Chemical Parameters}

Spring water samples were taken from the sampling points (Table 1), following protocol 1060 in Standard Methods for the Examination of Water and Wastewater [22], a description of which is shown in Table 2.

Table 2. Description of sampling for laboratory analysis.

\begin{tabular}{|c|c|c|c|c|}
\hline Parameter & Packaging Material & Maximum Period of Conservation & Sample Fraction & Volume (mL) \\
\hline Color & PEAD & $24 \mathrm{~h}$ & Total & 100 \\
\hline Fluoride & PEAD & $24 \mathrm{~h}$, no preservation & Total & 100 \\
\hline Hardness & PEAD & $24 \mathrm{~h}\left(4^{\circ} \mathrm{C}\right)$, no preservation & Total & 100 \\
\hline Total Coliforms and E. coli & Willpack bags & $24 \mathrm{~h}\left(4^{\circ} \mathrm{C}\right)$, no preservation & Total & 100 \\
\hline Metals & PEAD & $\begin{array}{l}\text { with } 2 \mathrm{~mL} \mathrm{HNO}_{3} / \mathrm{L} \\
\text { witimum }\end{array}$ & Total & 300 \\
\hline
\end{tabular}

Source: APHA [22].

Water analyses were carried out in the field and in the laboratory with protocols found in the Standard Methods for the Examination of Water and Wastewater [22] and multi-parameter use manuals (Table 3).

For the quantification of metals, standard curves were prepared with solutions of aluminum (Al), arsenic (As), boron (B), barium (Ba), cadmium (Cd), chromium (Cr), copper $(\mathrm{Cu})$, iron $(\mathrm{Fe})$, manganese $(\mathrm{Mn})$, calcium $(\mathrm{Ca})$, potassium $(\mathrm{K})$, sodium $(\mathrm{Na})$, magnesium $(\mathrm{Mg})$, cobalt $(\mathrm{Co})$, nickel $(\mathrm{Ni})$, lead $(\mathrm{Pb})$, and antimony $(\mathrm{Sb})$ (Calibration STD, SCP Science), calibrated in an Inductively Coupled Plasma-Optical Emission Spectrometer, ICP-OES 9820 Shimadzu, with a regression coefficient, $\mathrm{R}^{2}$, of higher than 0.995 for all cases. The water readings were performed in axial mode, in quadruplicate, with rinses between samples of $30 \mathrm{~s}$ at $60 \mathrm{rpm}$, and gas flow of $10 \mathrm{~L} / \mathrm{min}$ with plasma exposure of $30 \mathrm{~s}$.

\subsection{Analysis of Data}

Comparison between water sources within a season was carried out through a paired Student's $t$-test, and between seasons, an ANOVA and Tukey test at $5 \%$ was applied. Pearson's correlation was applied, which resulted in a principal component analysis (PCA). Sampling locations and contour representation of the parameters in the study area were performed in ArcGIS 10 (Esri, Redlands, CA, USA). 
Table 3. Analysis methods for water quality parameters.

\begin{tabular}{|c|c|c|c|c|}
\hline Parameter & Method & Unit & Reference & Place \\
\hline Turbidity & Selective electrode & NTU & $\begin{array}{l}\text { User's manual, Hanna } \\
\text { Multiparameter-HI } 9828\end{array}$ & On field \\
\hline True color & Spectrometric-Pt-CO method & TCU & 2120-C, Standard Methods [22] & In laboratory \\
\hline $\mathrm{pH}$ & Selective electrode & - & $\begin{array}{l}\text { User's manual, Hanna } \\
\text { Multiparameter-HI } 9828\end{array}$ & On field \\
\hline Dissolved oxygen (DO) & Selective electrode & $\mathrm{mg} \mathrm{O}_{2} / \mathrm{L}$ & $\begin{array}{l}\text { User's manual, Hanna } \\
\text { Multiparameter-HI } 9828\end{array}$ & On field \\
\hline Hardness & EDTA titration & $\mathrm{mgCO}_{3}{ }^{2-} / \mathrm{L}$ & 2340-C, Standard Methods [22] & In laboratory \\
\hline Conductivity & Selective electrode & $\mu S / \mathrm{cm}$ & $\begin{array}{l}\text { User's manual, Hanna } \\
\text { Multiparameter-HI } 9828\end{array}$ & On field \\
\hline TDS (Total dissolved solids) & Selective electrode & $\mathrm{mg} / \mathrm{L}$ & $\begin{array}{l}\text { User's manual, Hanna } \\
\text { Multiparameter-HI } 9828\end{array}$ & On field \\
\hline Fluoride & SPADNS colorimetric method & $\mathrm{mg} \mathrm{F}^{-} / \mathrm{L}$ & 4500-D, Standard Methods [22] & In laboratory \\
\hline E. coli, Total coliforms & Colorimetric & $\mathrm{MPN} / 100 \mathrm{~mL}$ & $\begin{array}{l}\text { Colilert-18/Quanti-Tray Method } \\
\text { 9308-2:2014 [23] }\end{array}$ & In laboratory \\
\hline
\end{tabular}

\section{Results and Discussion}

One of the most important aspects of water for human consumption is color, which is associated with inorganic and organic substances dissolved and in suspension in water. Consequently, it is directly related to human health and well-being [24,25]. The results of color and turbidity are shown in Table 4: a maximum value of 19.0 TCU and a minimum of $0.0 \mathrm{TCU}$ were observed in the dry season $(p<0.05)$, while in the rainy season, a maximum of 17.67 TCU $(p<0.05)$. In Figure 3 , it is observed that the sampling points from Chiara $(\mathrm{CH})$, Talavera (T), and Andahuaylas (A) present lower color values for both seasons, even reaching values of $0.0 \mathrm{TCU}$, while the water sources from San Jerónimo reported slightly high values above 5.0 TCU; however, most of the points for both seasons (16 sources in dry season and 15 sources in rainy season) presented values within the WHO [16] and ECA-Perú [18] recommended guidelines.

Table 4. Values of water quality parameters for human consumption.

\begin{tabular}{|c|c|c|c|c|c|c|c|c|c|c|c|c|c|}
\hline \multirow{2}{*}{ Parameters } & \multirow{2}{*}{ WHO [14] } & \multirow{2}{*}{$\mathbf{E C A}^{* * *}$} & \multicolumn{4}{|c|}{ Dry Season } & \multicolumn{6}{|c|}{ Rainy Season } & \multirow{2}{*}{$p^{* *}$} \\
\hline & & & Max & Min & \pm & CV (\%) & $p^{*}$ & Max & Min & \pm & CV (\%) & $p^{*}$ & \\
\hline Color & 15 & 15 & 19.00 & 0.00 & 5.11 & 179.79 & $<0.05$ & 17.67 & 0.00 & 5.93 & 160.86 & $<0.05$ & 0.649 \\
\hline $\mathrm{pH}$ & $6.5-8.0$ & $6.5-8.0$ & 8.32 & 6.71 & 0.46 & 6.13 & $<0.05$ & 8.53 & 7.33 & 0.35 & 4.36 & $<0.05$ & 0.973 \\
\hline Conductivity & - & 1500 & 655.50 & 63.00 & 176.05 & 55.50 & $<0.05$ & 578.25 & 53.25 & 148.19 & 57.71 & $<0.05$ & 0.018 \\
\hline TDS & 1000 & 1000 & 327.25 & 32.50 & 87.80 & 55.18 & $<0.05$ & 290.00 & 25.50 & 74.54 & 57.81 & $<0.05$ & 0.018 \\
\hline Turbidity & 0.5 & 5 & 24.58 & 0.00 & 7.60 & 271.16 & $<0.05$ & 24.33 & 0.00 & 6.03 & 341.27 & $<0.05$ & 0.641 \\
\hline Hardness & $100-300$ & 500 & 355.80 & 77.70 & 70.15 & 26.27 & $<0.05$ & 314.20 & 66.10 & 60.99 & 26.59 & $<0.05$ & 0.000 \\
\hline $\mathrm{DO}$ & - & 6 & 7.03 & 2.54 & 1.39 & 30.33 & $<0.05$ & 7.37 & 2.05 & 1.46 & 33.76 & $<0.05$ & 0.291 \\
\hline Fluoride & 1.5 & 1.5 & 0.81 & 0.00 & 0.24 & 71.99 & $<0.05$ & 0.58 & 0.02 & 0.15 & 48.04 & $<0.05$ & 0.081 \\
\hline
\end{tabular}

${ }^{*}$ Evaluated by Tukey's test at $5 \%$ significance. ${ }^{* *}$ Between seasons, evaluated by $t$-test for paired samples at $5 \%$ significance. ${ }^{* * *}$ Water quality, Category 1, Subcategory A1 [18].

The study area with an altitude higher than $3500 \mathrm{~m}$ is largely covered by ichu (Stipa ichu) and a few native plants, such as puna muña. These plants supply dissolved organic compounds, for instance humic substances [26], which directly influence water color, and values of $0.0 \mathrm{TCU}$ are reported due to the low floral density of the study areas. On the other hand, the color of the water is also influenced by the presence of metals, such as iron, and the geology of the areas of the study show high levels of rocks with iron content $[10,27,28]$.

The $\mathrm{pH}$ of water in the rainy season had a maximum of 8.53 and a minimum of 7.33 $(p<0.05)$, while in the dry season, a maximum of 8.32 and a minimum of $6.71(p<0.05)$ were reported (Table 4). There was no significant difference in both seasons $(p=0.973)$. On the other hand, in the Chiara area $(\mathrm{CH}), \mathrm{pH}$ values were higher than 8.0 in both seasons (Figure $4 a, b$ ). This could be influenced by metallurgical mining extraction at the head of the basin, where rocks have high carbonate content, as evidenced by the high hardness values (Table 4). In the springs of the districts of Andahuaylas, San Jerónimo, and Talavera, the $\mathrm{pH}$ levels are within the limits established by the WHO [14] and ECA-Peru [18]. 

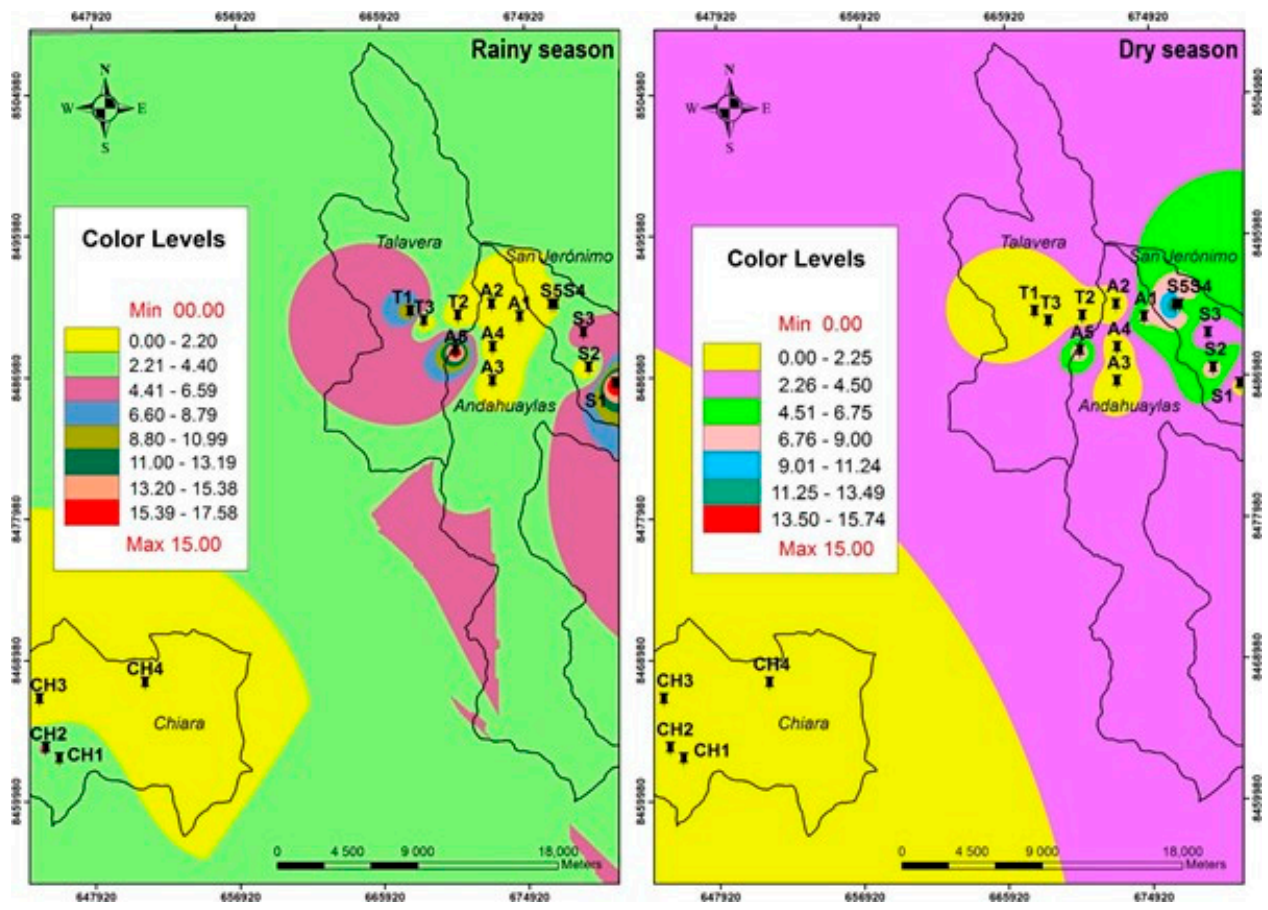

Figure 3. Variation of water color level in sampling areas.

The variation in $\mathrm{pH}$ between points could be due to the fact that the groundwater passes through different mantles or water tables, dissolving mainly inorganic material, such as carbonates and salts $[29,30]$, which confer alkaline $\mathrm{pH}$, especially in the rainy season.

Regarding the conductivity of water, which measures the total content of ionizable salts, which allows flow of electric current through water [28,31,32], water sources present values in the range from 63.00 to $655.50 \mu \mathrm{S} / \mathrm{cm}$ in the dry season $(p<0.05)$ and from 53.25 to $578.25 \mu \mathrm{S} / \mathrm{cm}$ in the rainy season $(p<0.05)$ (Table 4$)$, observing significant differences between seasons $(p=0.018)$ (Figure $4 c, d)$, and some points exceed the values recommended by the ECA-Peru [18].

TDS is an indicator that allows knowing the quality of groundwater due to changes in the chemical composition [30,32]; thus, TDS values were reported as 327.25 and $32.50 \mathrm{mg} / \mathrm{L}$ in the dry season $(p<0.05)$ and 290.0 and $25.50 \mathrm{mg} / \mathrm{L}$ in the rainy season, as maximum and minimum values respectively $(p<0.05)$, observing significant differences between seasons $(p=0.018)$ (Table 4$)$. The Chiara area reported lower TDS values for both seasons (Figure 5a,b), and it shows a decrease in the rainy season, being a characteristic behavior due to the increase in solvent (water) [33,34]. However, in all sampling points, the TDS values do not exceed the limits recommended by the WHO [14] and ECA-Peru [18].

The turbidity of water for human consumption is attributed to the content of clays, silt, organic matter, and suspended microorganisms, whose presence in high concentrations affects water quality [28]. It was observed that the majority of springs presented low values in reference to what is recommended by the WHO [16] and ECA-Peru [16] (Figure 5c,d), showing no significant difference between seasons $(p=0.641)$; however, it was observed that at point A2 in the dry season, and T2 and A3 in the rainy season, high values were reported, reaching a maximum of 24.58 and 24.33 NTU, respectively (Table 4). The low turbidity values are due to the fact that the groundwater that sprouts in springs does not have urban anthropic interaction, and to the pressure of the water table, which allows the precipitation of suspended solids [25,35]. 

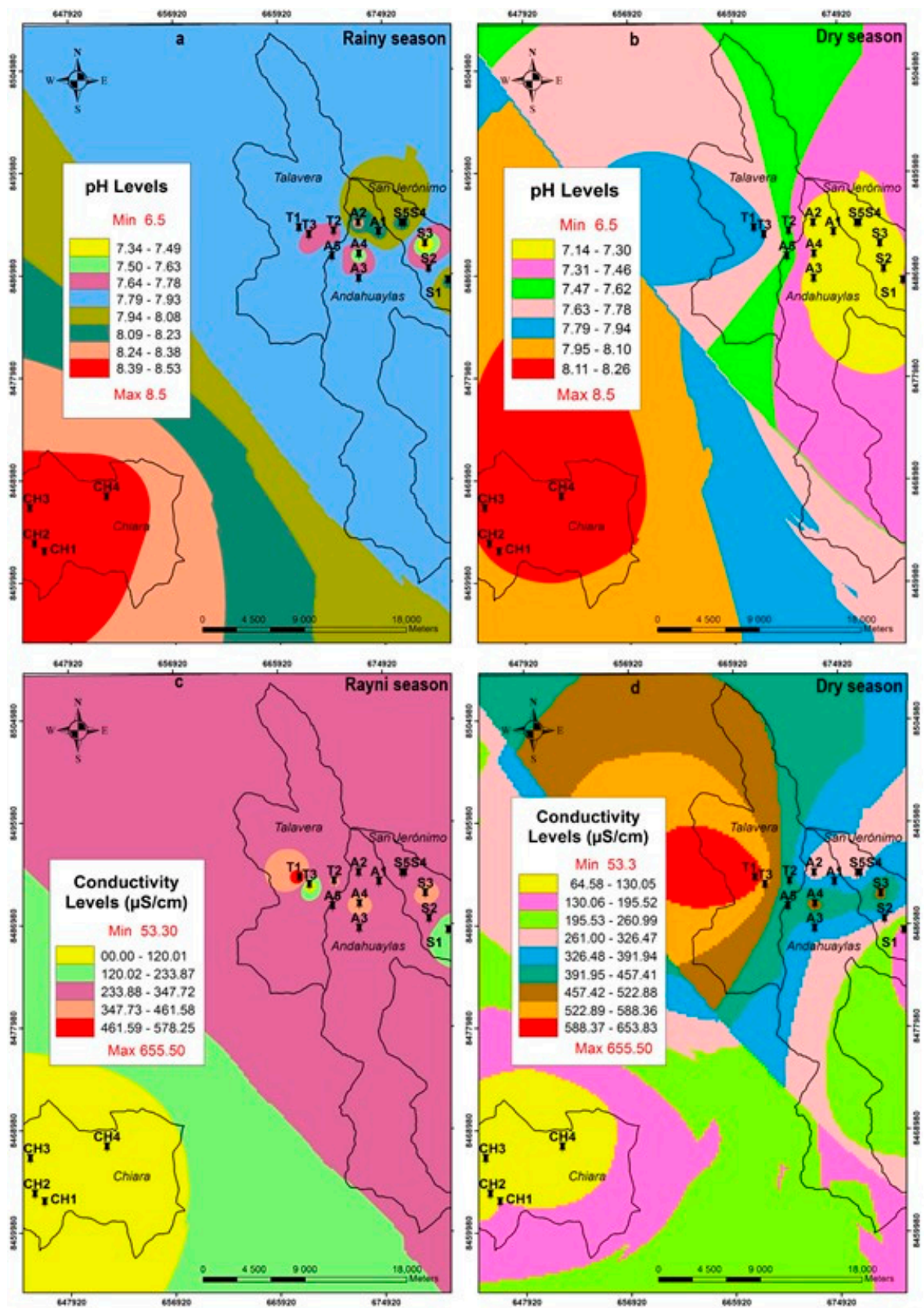

Figure 4. (a) $\mathrm{pH}$ in rainy season, (b) $\mathrm{pH}$ in dry season, (c) conductivity in rainy season, and (d) conductivity in dry season, in the sampling areas.

Calcium and magnesium carbonate in water represent the total hardness, and these vary with the geology of the area, considerably influencing the taste of the water, although the taste threshold varies between people $[27,30,36]$. It was found that the springs have a hardness content that varies from 77.70 to $355.80 \mathrm{mg} / \mathrm{L}$ in the dry season $(p<0.05)$, and from 66.10 to $314.20 \mathrm{mg} / \mathrm{L}$ in the rainy season $(p<0.05)$, showing a significant difference between seasons $(p=0.000)$. It was observed that Talavera and Andahuaylas areas presented a greater number of sources with high hardness values, while the Chiara springs presented greater variability (Figure 5e,f), however, they are within the permissible levels by the ECA-Peru, and slightly higher than those established by the WHO [16]. 

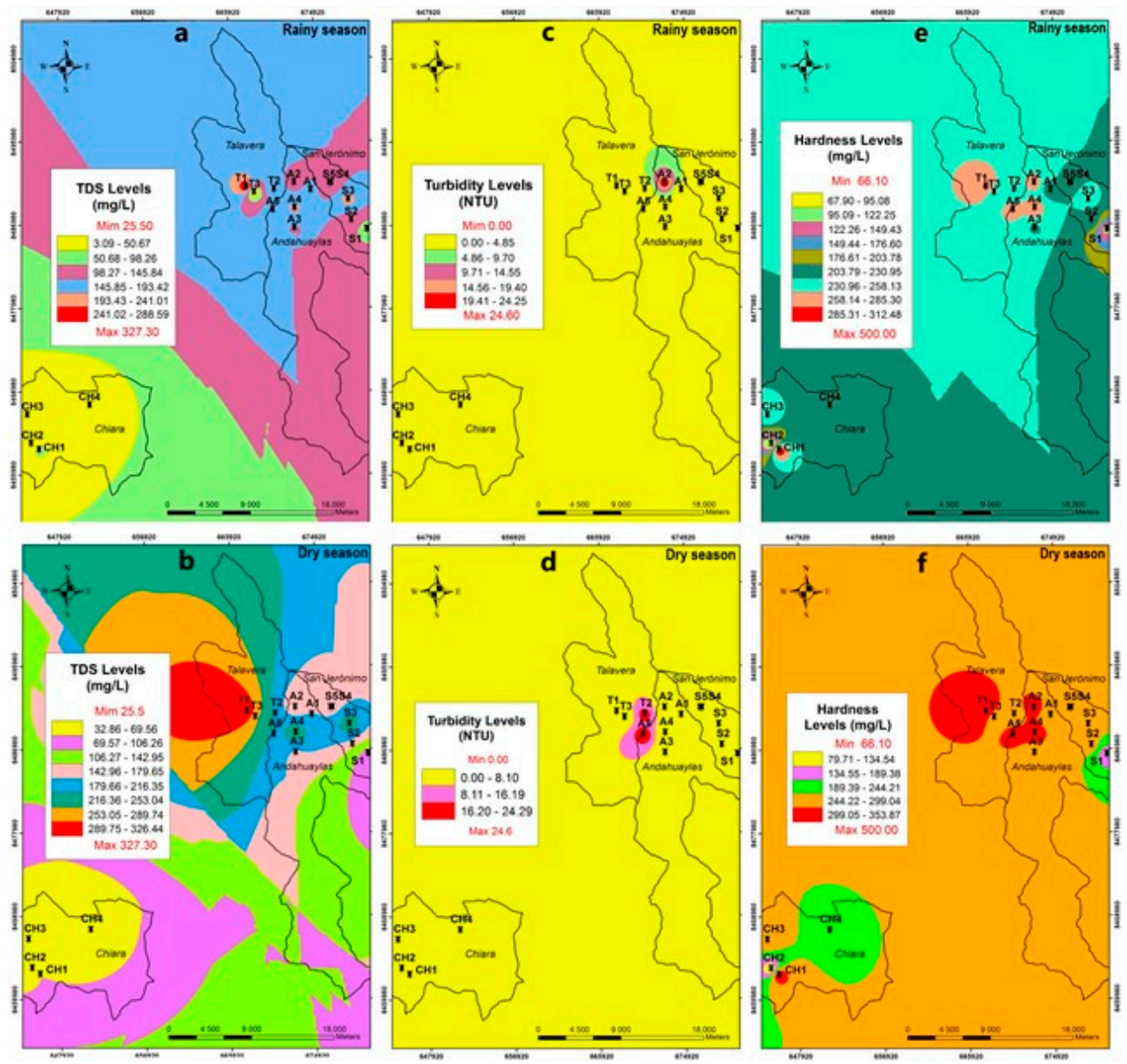

Figure 5. (a) TDS in rainy season, (b) TDS in dry season, (c) turbidity in rainy season, (d) turbidity in dry season (e), hardness in rainy season, and (f) hardness in dry season, in the sampling areas.

In the same way, the level of dissolved oxygen (DO) was found in the range from 2.54 to $7.03 \mathrm{mg} / \mathrm{L}$ in the dry season, and from 2.05 to $7.37 \mathrm{mg} / \mathrm{L}$ in the rainy season, with no significant differences between seasons $(p=0.291)$ (Table 4$)$. Although this parameter is not considered critical in terms of water quality for human consumption $[16,18]$, low DO values would be an indicator of contamination due to leachate and runoff in groundwater [35,37], and in natural waters these should be above $5.0 \mathrm{mg} / \mathrm{L}$.

Regarding the fluorides level, it was observed that it is in the range from 0.00 to $0.81 \mathrm{mg} / \mathrm{L}$ in the dry season $(p<0.05)$, and from 0.02 to $0.58 \mathrm{mg} / \mathrm{L}$ in the rainy season $(p<0.05)$, and it shows no significant differences between seasons $(p=0.081)$ (Table 4$)$. The levels found do not exceed the limits established by the WHO [16] and ECA-Peru [16], and it was observed that fluoride levels increase in the dry season (Figure 6) due to evaporation, while the opposite happens in the rainy season, due to dilution. A similar behavior was reported by Amenu et al. [1] and Davraz et al. [38]. 

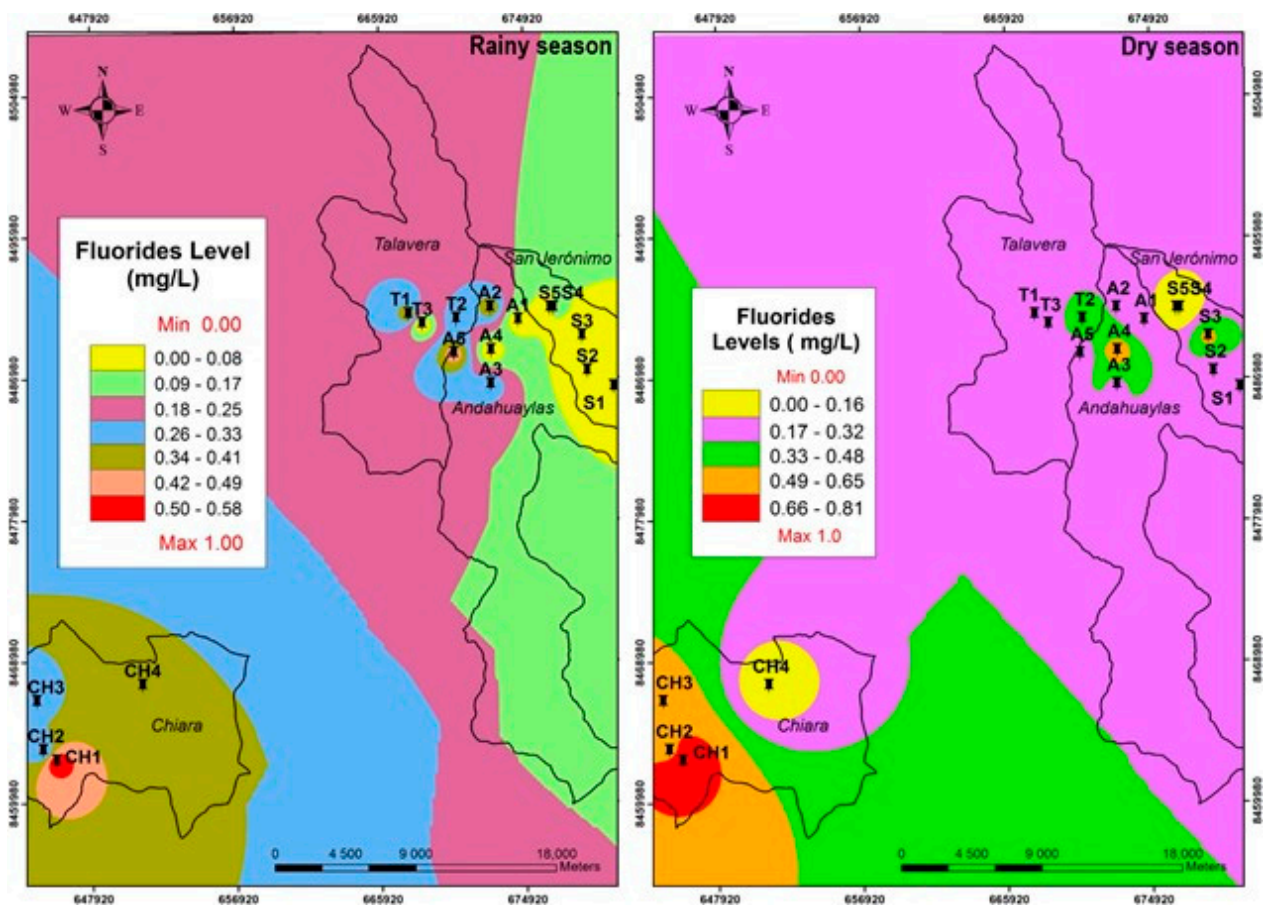

Figure 6. Variation of water fluoride level in the sampling areas.

High levels of fluoride in the water indicate anthropic contamination, which can cause staining of the teeth, osteosclerosis, anemia, and hypothyroidism [39,40], while lower concentrations are due to sedimentary rocks [41,42]. This content favors dental and bone health of the population [16,43].

Regarding metals, it was observed that $\mathrm{As}, \mathrm{Sb}$, and $\mathrm{Pb}$ were found above the permissible levels by WHO [16] and ECA-Peru [18] for both seasons, while Cd exceeded the levels in the dry season, and in the $\mathrm{A} 5$ and $\mathrm{CH} 2$ points in the rainy season (Table 5). The main sources of metal present in water are associated with erosion and removal of soils due to mining $[44,45]$.

Table 5. Description of the metal levels in water sources.

\begin{tabular}{|c|c|c|c|c|c|c|c|c|c|c|c|}
\hline \multirow{2}{*}{$\begin{array}{l}\text { Metal } \\
(\mathrm{mg} / \mathrm{L})\end{array}$} & \multirow{2}{*}{ WHO [14] } & \multirow{2}{*}{ ECA * } & \multicolumn{2}{|c|}{ Excess Metals } & \multicolumn{3}{|c|}{ Dry Season } & \multicolumn{3}{|c|}{ Rainy Season } & \multirow{2}{*}{$p^{* * * *}$} \\
\hline & & & Dry Season & Rainy Season & Max & Min & $p^{* * *}$ & Max & Min & $p^{*}$ & \\
\hline $\mathrm{Al}$ & 0.900 & 0.900 & None & None & 0.204 & 0.033 & $<0.05$ & 0.163 & 0.007 & $<0.05$ & 0.000 \\
\hline $\mathrm{Sb}$ & 0.020 & 0.020 & All & All & 0.952 & 0.194 & $<0.05$ & 0.813 & 0.053 & $<0.05$ & 0.000 \\
\hline As & 0.010 & 0.010 & All & All & 0.251 & 0.034 & $<0.05$ & 0.194 & 0.003 & $<0.05$ & 0.000 \\
\hline $\mathrm{Ba}$ & 1.300 & 0.700 & None & None & 0.086 & 0.001 & $<0.05$ & 0.104 & 0.000 & $<0.05$ & 0.005 \\
\hline $\mathrm{B}$ & 2.400 & 2.400 & None & None & 0.019 & 0.000 & $<0.05$ & 0.011 & 0.000 & $<0.05$ & 0.029 \\
\hline $\mathrm{Cd}$ & 0.003 & 0.003 & All & $\begin{array}{l}\text { All except A5 } \\
\text { and } \mathrm{CH} 2\end{array}$ & 0.042 & 0.006 & $<0.05$ & 0.031 & 0.001 & $<0.05$ & 0.000 \\
\hline $\mathrm{Cu}$ & 2.000 & 2.000 & None & None & 0.066 & 0.010 & $<0.05$ & 0.024 & 0.002 & $<0.05$ & 0.000 \\
\hline $\mathrm{Cr}$ & 0.050 & 0.050 & Only T1 & None & 0.054 & 0.007 & $<0.05$ & 0.037 & 0.000 & $<0.05$ & 0.000 \\
\hline $\mathrm{Fe}$ & 2.000 & 0.300 & None & None & 0.076 & 0.001 & $<0.05$ & 0.081 & 0.004 & $<0.05$ & 0.984 \\
\hline $\mathrm{Mn}$ & 0.400 & 0.400 & None & None & 0.019 & 0.002 & $<0.05$ & 0.014 & 0.002 & $<0.05$ & 0.001 \\
\hline $\mathrm{Ni}$ & 0.070 & 0.070 & Only T1, T2, T4 & Only T1 & 0.100 & 0.025 & $<0.05$ & 0.080 & 0.000 & $<0.05$ & 0.000 \\
\hline $\mathrm{Pb}$ & 0.010 & 0.010 & All & All & 0.271 & 0.039 & $<0.05$ & 0.203 & 0.010 & $<0.05$ & 0.000 \\
\hline $\mathrm{Co}^{* *}$ & - & 1.000 & None & None & 0.123 & 0.012 & $<0.05$ & 0.121 & 0.006 & $<0.05$ & 0.048 \\
\hline $\mathrm{Na}$ & 200 & - & None & None & 0.696 & 0.105 & $<0.05$ & 0.807 & 0.178 & $<0.05$ & 0.001 \\
\hline $\mathrm{Mg}$ & 150 & - & None & None & 9.054 & 1.064 & $<0.05$ & 9.994 & 1.284 & $<0.05$ & 0.722 \\
\hline $\mathrm{K}$ & 30 & - & None & None & 4.519 & 0.127 & $<0.05$ & 4.522 & 0.197 & $<0.05$ & 0.000 \\
\hline $\mathrm{Ca}$ & 200 & - & None & None & 4.076 & 0.305 & $<0.05$ & 2.696 & 0.279 & $<0.05$ & 0.118 \\
\hline
\end{tabular}

${ }^{*}$ Water quality, Category 1, Subcategory A1 [18]. ** Category 3: Animal Drink [18]. ${ }^{* * *}$ Evaluated by Tukey's test at 5\% significance. **** Between seasons, evaluated by $t$-test for paired samples at $5 \%$ significance. 
The intake of metals through water above its permissible levels can cause health problems $[13,46,47]$. The intake of $\mathrm{Pb}$, for example, can generate cancer risk, mental retardation in children, hypertension in pregnant women, and problems in peripheral nerve function [2,48], which is a determinant in maternal blood [13].

High levels of As have become a global public and environmental health problem since groundwater is naturally contaminated with As throughout the world [49], being responsible for skin problems, lung, bladder, liver, and uterus carcinogens, even at levels between 5 and $10 \mathrm{ug} / \mathrm{L}$ in drinking water [49-51].

The presence of $\mathrm{Cd}$ at higher levels than recommended generates carcinogenic risks [2], and produces symptoms such as nausea, vomiting, respiratory difficulties, cramps, and loss of consciousness [49]. Regarding Sb, although it is not bio-accumulative, high levels report risks of lung cancer and skin problems [52,53].

$\mathrm{Mg}$ reported higher content in water sources (Figure 7), followed by $\mathrm{Ca}, \mathrm{K}$, and $\mathrm{Na}$ in both seasons, although these are within the limits established by the WHO [16] and ECA-Peru [18] (Table 5), and the same was seen for Al, Ba, B, Cu, Cr, Fe, Mn, and Co in both seasons. Fe, $\mathrm{Mg}$, and Ca showed no significant difference between seasons $(p>0.05)$. Regarding Ni in dry seasons, it was observed that points T1, T2, and T4, corresponding to the Talavera district, reported higher recommended values, and the same for $\mathrm{Cr}$ in T1 (Table 5).
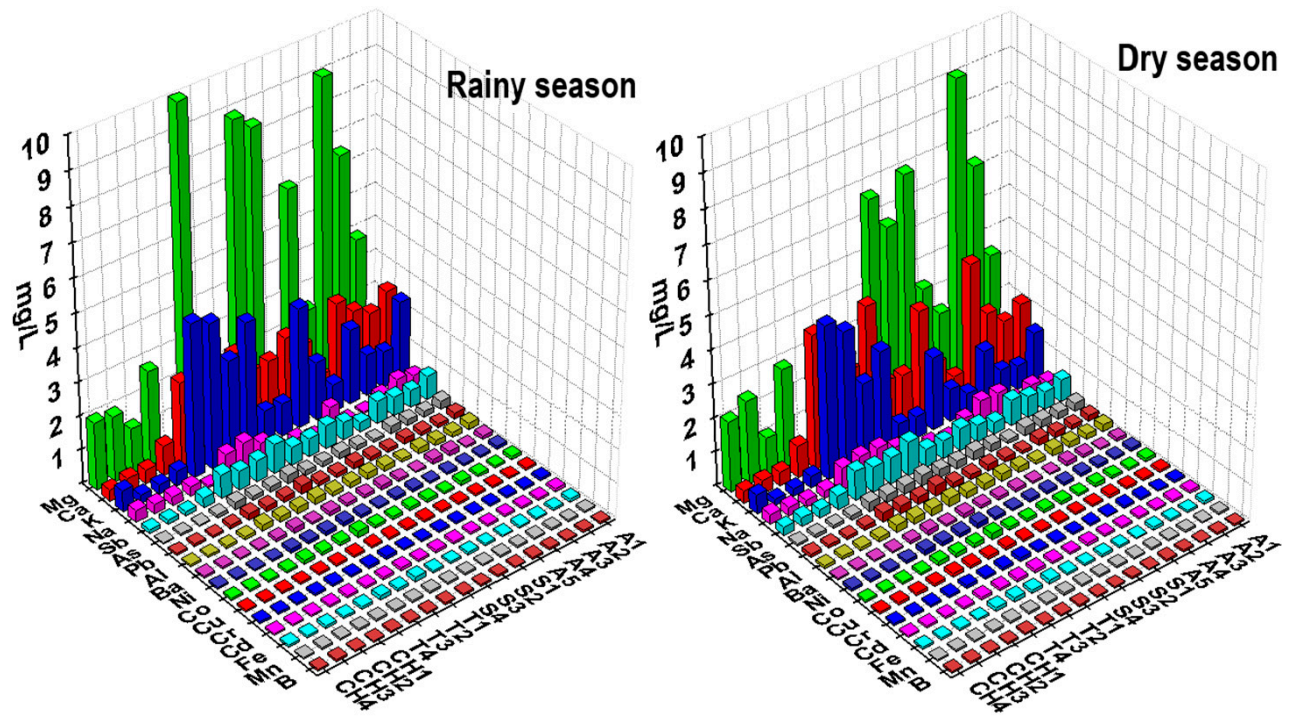

Figure 7. Variation of metal levels in water sources.

Water sources A4 and A5 in the Andahuaylas district, S2 in San Jerónimo, and T1 and T3 in Talavera for the dry season reported TC levels above those recommended by ECA-Peru [18] (Table 6). The same was seen for sources A5, S4, T1, T3, and CH2 in the rainy season; however, according to $\mathrm{WHO}$ [16], all water sources exceed the permissible level for water for human consumption $(0.0 \mathrm{MPN} / 100 \mathrm{~mL})$. Regarding E. coli, it was observed that all the points present $<1 \mathrm{MPN} / 100 \mathrm{~mL}$, with the sources T3 and T1 being more contaminated in the dry season, and $\mathrm{T} 1$ in the rainy season (Table 6). In that sense, all sources exceed the admissible levels recommended by the WHO [16] and ECA-Peru [18]. 
Table 6. Total coliforms (TC) and E. coli in water sources (MPN/100 mL).

\begin{tabular}{ccccc}
\hline \multirow{2}{*}{ Water Sources } & \multicolumn{2}{c}{ Dry Season } & \multicolumn{2}{c}{ Rainy Season } \\
\cline { 2 - 5 } & TC & E. coli & TC & E. coli \\
\hline A1 & 5.2 & $<1$ & 4.1 & $<1$ \\
A2 & 27.5 & $<1$ & 4.1 & $<1$ \\
A3 & 1 & $<1$ & $<1$ & $<1$ \\
A4 & 344.1 & $<1$ & 12.1 & $<1$ \\
A5 & 248.1 & 1 & 71.7 & $<1$ \\
\hline S1 & $<1$ & $<1$ & 6.3 & $<1$ \\
S2 & 214.2 & 1 & 96 & $<1$ \\
S3 & 1 & $<1$ & 5.1 & $<1$ \\
S4 & 12.1 & $<1$ & 17.5 & 7.5 \\
T1 & 2419.6 & 5.2 & 2419.6 & $<1$ \\
T2 & 13.4 & $<1$ & $<1$ & $<1$ \\
T3 & 866.4 & 101.9 & $<1$ & $<1$ \\
T4 & $<1$ & $<1$ & $<1$ & $<1$ \\
\hline CH1 & 1 & $<1$ & 61.3 & $<1$ \\
CH2 & $<1$ & $<1$ & $<1$ & $<1$ \\
CH3 & $<1$ & $<1$ & 10.9 & 0 \\
CH4 & 3.1 & $<1$ & 0 & 0 \\
\hline WHO & 0 & 0 & $<0.50$ &
\end{tabular}

* Water quality, Category 1, Subcategory A1 [18].

Pearson's correlation evaluation (Rs) of the 27 water quality parameters, of the water sources for the dry season, indicated that the majority present correlation (at $5 \%$ significance), especially between metals, conductivity, and TDS (Rs >0.7), and this allowed to perform a principal component analysis (PCA) [30,54].

The PCA showed 3 principal components (PC), indicating $80.0 \%$ of the variability (Figure 8a), and the commonalities were greater than 0.5 in all cases, which suggests that this model would allow for explaining the variability of the parameters. The factor loadings are shown in Table 7 , and the following classification criterion was considered: strong > 0.75, moderate $0.50-0.74$, and weak $0.30-0.49$ [34].

The PC1 explained $59.61 \%$ of the variability and had strong loadings for metals (except for $\mathrm{Mg}, \mathrm{Na}$, and $\mathrm{Cu}$ ), Conductivity (C), and TDS (Table 7), and this is an indication that water for human consumption in high Andean water sources is influenced by the presence of cations. This could be attributed to the fact that the area is influenced by mining, with the leaching of the soils, which is confirmed by the strong charge of conductivity and TDS [55]. The fact that most of the charges are negative is an indication that sorption-desorption processes are influenced by the presence of cations $[34,56]$.

The PC2 explained $12.49 \%$ of variability, and its strong positive charge is attributed to turbidity, which would be due to the removal of soils in the high areas, due to mining activity, which infiltrates into the subsoil [42]. Likewise, $\mathrm{Mg}$ shows a strong negative charge, and this would evidence soil erosion [57], which influences the sorption-desorption processes in the chemical balance of carbonates $[57,58]$. PC 3 shows a strong positive charge for color, which is an aesthetic attribute of water [1].

The relationship shown in Figure 8b,c with respect to PC1 allows for observing that the water sources of Talavera, Andahuaylas (A1, A2, A3), and S2 present mostly metals in their composition, except for $\mathrm{Mg}$, although these could be outside or within the limits established by the WHO [16] and ECA-Peru [18], and would also be conditioned by their levels of TDS, E. coli, CT, color, and hardness, while the water sources of Chiara $(\mathrm{CH})$, Andahuaylas (A2, A5), and San Jerónimo (S1, S3, S4) would be conditioned by having high levels of $\mathrm{pH}$, and $\mathrm{DO}$. With respect to PC2, the water sources located in the upper part of 
the horizontal line in Figure $8 \mathrm{~b}, \mathrm{c}$ would be conditioned by turbidity, and the sources below the horizontal line would predominate in $\mathrm{Mg}$.
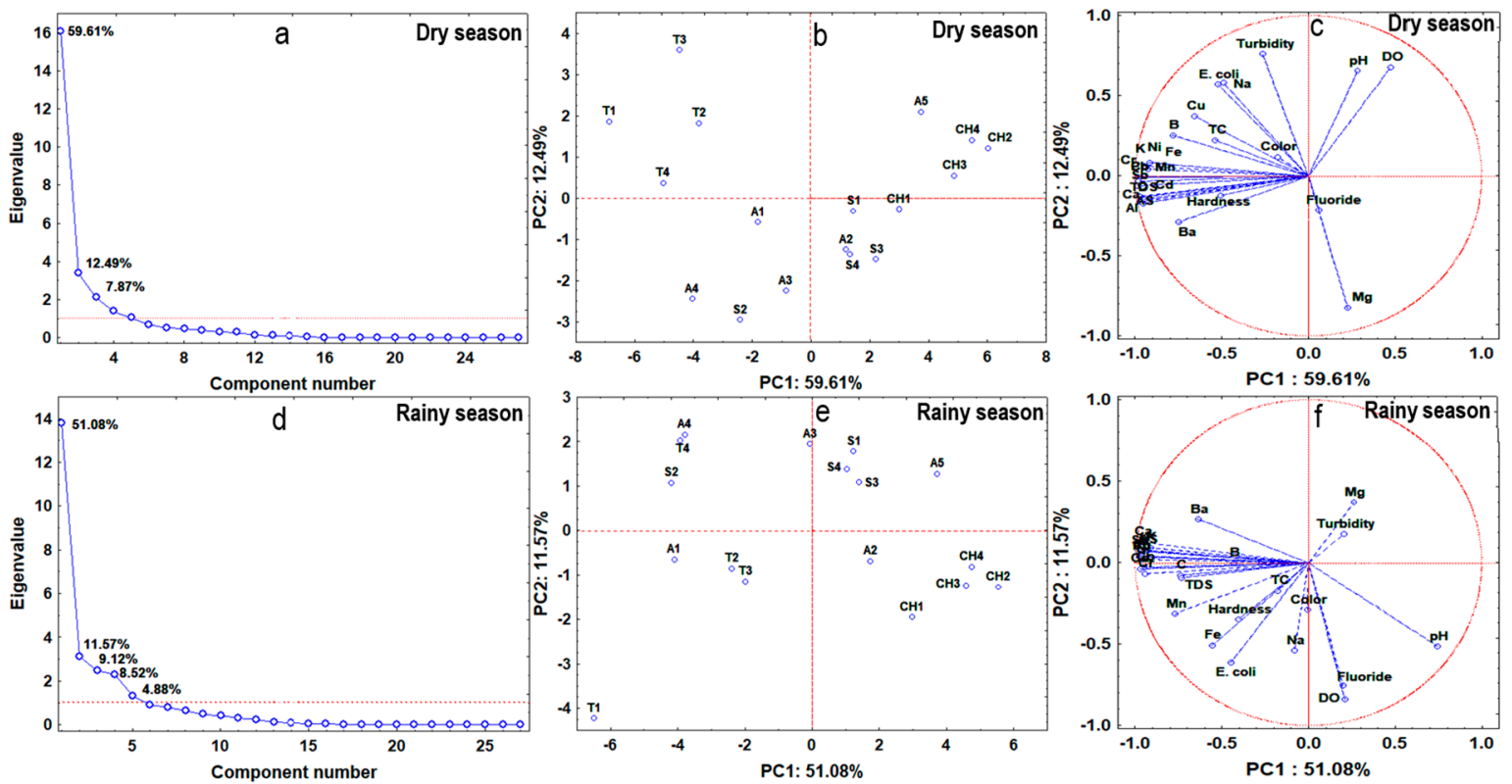

Figure 8. (a) Scree plot for the dry season, (b) scores plot for PC1 and PC2 in the dry season, (c) loadings plot for PC1 and PC2 in the dry season, (d) scree plot for the rainy season, (e) scores plot for PC1 and PC2 in the rainy season, and (f) loadings plot for PC1 and PC2 in the rainy season.

Table 7. Rotated component matrix by season.

\begin{tabular}{ccccccc}
\hline \multirow{2}{*}{ Parameters } & \multicolumn{2}{c}{ Dry Season Components } & \multicolumn{2}{c}{ Rainy Season Components } \\
\cline { 2 - 7 } & $\mathbf{1}$ & $\mathbf{2}$ & $\mathbf{3}$ & $\mathbf{1}$ & $\mathbf{2}$ & $\mathbf{3}$ \\
\hline $\mathrm{pH}$ & 0.281 & 0.655 & 0.399 & 0.743 & -0.516 & 0.079 \\
$\mathrm{C}$ & -0.965 & -0.133 & -0.086 & -0.738 & -0.076 & -0.421 \\
$\mathrm{TDS}$ & -0.964 & -0.134 & -0.082 & -0.736 & -0.090 & -0.435 \\
$\mathrm{DO}$ & 0.475 & 0.677 & 0.040 & 0.208 & -0.843 & -0.038 \\
$\mathrm{Color}$ & -0.180 & 0.116 & -0.781 & -0.008 & -0.292 & 0.047 \\
$\mathrm{H}$ & -0.509 & -0.122 & 0.560 & -0.405 & -0.352 & -0.480 \\
$\mathrm{~F}-$ & 0.056 & -0.210 & 0.607 & 0.196 & -0.758 & -0.385 \\
$\mathrm{~T}$ & -0.264 & 0.760 & -0.292 & 0.201 & 0.176 & -0.516 \\
$\mathrm{TC}$ & -0.538 & 0.224 & -0.296 & -0.178 & -0.169 & 0.053 \\
$\mathrm{E} . \mathrm{coli}$ & -0.525 & 0.569 & -0.055 & -0.451 & -0.616 & 0.041 \\
$\mathrm{Mg}$ & 0.225 & -0.828 & -0.127 & 0.259 & 0.370 & -0.699 \\
$\mathrm{Ca}$ & -0.975 & -0.164 & 0.033 & -0.960 & 0.127 & -0.070 \\
$\mathrm{~K}$ & -0.952 & 0.064 & -0.165 & -0.912 & 0.092 & -0.026 \\
$\mathrm{Na}$ & -0.491 & 0.581 & 0.000 & -0.084 & -0.541 & -0.468 \\
$\mathrm{Sb}$ & -0.985 & -0.061 & 0.010 & -0.983 & 0.072 & 0.020 \\
$\mathrm{AS}$ & -0.957 & -0.173 & -0.066 & -0.929 & 0.077 & -0.057 \\
$\mathrm{~Pb}$ & -0.984 & -0.007 & 0.045 & -0.974 & 0.037 & 0.038 \\
$\mathrm{Al}$ & -0.951 & -0.149 & -0.069 & -0.963 & 0.080 & -0.046 \\
$\mathrm{Ba}$ & -0.749 & -0.293 & -0.013 & -0.639 & 0.266 & -0.286 \\
$\mathrm{Ni}$ & -0.925 & 0.045 & 0.252 & -0.963 & 0.025 & 0.031 \\
$\mathrm{Co}$ & -0.979 & -0.008 & -0.008 & -0.950 & -0.028 & -0.002 \\
$\mathrm{Cu}$ & -0.660 & 0.372 & 0.566 & -0.967 & 0.045 & 0.045 \\
$\mathrm{Cr}$ & -0.954 & -0.004 & 0.127 & -0.944 & -0.065 & 0.080 \\
$\mathrm{Cd}$ & -0.975 & -0.128 & -0.006 & -0.969 & -0.038 & -0.013 \\
$\mathrm{Fe}$ & -0.919 & 0.083 & -0.047 & -0.559 & -0.509 & 0.380 \\
$\mathrm{Mn}$ & -0.980 & -0.033 & 0.065 & -0.772 & -0.318 & 0.287 \\
$\mathrm{~B}$ & -0.784 & 0.252 & -0.135 & -0.434 & 0.000 & 0.632 \\
\hline
\end{tabular}

Where: $\mathrm{C}$, conductivity, $\mathrm{H}$, hardness, $\mathrm{T}$, turbidity, TC, Total coliforms. 
The PCA in the rainy season allowed to identify 3 PCs (Figure 8d), representing $71.2 \%$ of the variability, whose factor loadings are shown in Table 7. PC1 explained 51.8\% of the variability and had a strong charge for metals (except for $\mathrm{Mg}, \mathrm{Na}, \mathrm{Ba}, \mathrm{Fe}$, and B), $\mathrm{pH}$, Conductivity (C), and TDS (Table 7), being an indication that water for human consumption in high Andean water sources is influenced by the presence of cations, which is confirmed by the $\mathrm{pH}$ load, Conductivity (C), and TDS. This behavior is due to the presence of extractive mining in the high Andean zones, which remove the soils and rocks, and due to the effect of the rain leach cations and salts, which infiltrate into the water table.

However, these are in a continuous sorption-desorption process, so the values of the charges are negative $[34,56]$. Regarding PC2, it was observed that the level of DO and fluorides is influenced.

In the rainy season, the water sources from Talavera (T) and A1, A4, and S2 mainly present metals in their composition, except for $\mathrm{Mg}$, and are conditioned by the levels of TDS, hardness, conductivity, E. coli, and CT (Figure 8e,f), while the water sources of Chiara $(\mathrm{CH}), \mathrm{S} 1, \mathrm{~S} 3, \mathrm{~S} 4, \mathrm{~A} 2$, and $\mathrm{A} 5$ would be conditioned to the levels of $\mathrm{Mg}$, turbidity, $\mathrm{pH}$, fluorides, and DO.

In general, the water sources from Andahuaylas and Talavera are mainly conditioned by the presence of metals, while the sources from Chiara and San Jerónimo would be conditioned by the presence of $\mathrm{Mg}$ and the physicochemical parameters of the water, the latter of which is within the permissible limits recommended by the WHO [16] and ECA-Peru [18].

However, these water sources receive little attention in terms of monitoring water quality parameters, performing only microbiological controls (total and thermotolerant coliforms) and residual chlorine, due to the number of cases of diarrhea and gastrointestinal infections, especially among children in the areas of influence $[59,60]$. On the other hand, the presence of microorganisms such as diatoms, copepods, and native algae has been observed in the springs of the study areas, and these are a good biological indicator of water quality in its natural state [10]. The results suggest that the latency limits for these biological markers in the water have not yet been considerably exceeded, so that the water of the high Andean springs of Apurimac would still maintain its natural qualities, except for the excessive level of heavy metals present.

\section{Conclusions}

It has been observed that the high Andean water sources (springs) in Andahuaylas, San Jerónimo, Talavera, and Chiara districts, located between 2805 and $4004 \mathrm{~m}$ altitude, would be influenced by the presence of extractive mining activity in the headwaters of the basin, due to the presence of metals $(\mathrm{Sb}, \mathrm{As}, \mathrm{Cd}, \mathrm{Pb})$ above the permissible levels for water for human consumption, with a greater impact during the dry season $(p<0.05)$. In the same way, it would affect the physicochemical parameters that are related to the presence of cations and particulate matter. The PCA evaluated for the dry and rainy seasons showed that the water sources would be conditioned by the presence of metals, especially in the zones of Andahuaylas and Talavera, as well as the parameters that imply dissolved solids in the water (turbidity and fluorides).

The control of legal and illegal mining activities would allow for reducing the levels of heavy metals in the water, considering places of disposal of segregated materials and use of rational water for mineral leaching, implementing dynamic monitoring of springs and groundwater, which would allow safe water to be available in low-lying and urbanized zones. 
Author Contributions: Conceptualization, D.C.-Q., G.I.B.-P. and H.P.-R.; methodology, D.C.-Q., B.S.R.-P., L.M.Z.-P. and C.A.L.-S.; software, Y.C.-Q., formal analysis, D.C.-Q., B.S.R.-P., C.A.L.-S., F.T.-P., A.M.S.-R. and D.E.P.-G.; investigation, D.C.-Q., S.F. and C.A.L.-S.; writing-original draft preparation, D.C.-Q., Y.C.-Q. and F.T.-P.; writing-review and editing, D.C.-Q., S.F. and D.E.P.-G.; supervision D.C.-Q. and S.F., funding acquisition, D.C.-Q.All authors have read and agreed to the published version of the manuscript.

Funding: This research was funded by Vicepresidencia de Investigación de la Universidad Nacional José María Arguedas, Andahuaylas, Apurímac, Perú.

Institutional Review Board Statement: Not applicable.

Informed Consent Statement: Not applicable.

Data Availability Statement: The data presented in this study are available in this same article.

Acknowledgments: The authors would like to thank the Vice-Presidency of Research of the Universidad Nacional José María Arguedas for the financing and use of the water analysis and control research laboratory. Additionally, thanks to the representatives of the JASS of Andahuaylas, San Jerónimo, Talavera, and Chiara, for providing us the facilities for sampling.

Conflicts of Interest: The authors declare no conflict of interest.

\section{References}

1. Amenu, K.; Markemann, A.; Valle Zárate, A. Water for human and livestock consumption in rural settings of Ethiopia: Assessments of quality and health aspects. Environ. Monit. Assess. 2013, 185, 9571-9586. [CrossRef] [PubMed]

2. Nkpaa, K.W.; Patrick-Iwuanyanwu, K.C.; Wegwu, M.O.; Essien, E.B. Health risk assessment of hazardous metals for population via consumption of seafood from Ogoniland, Rivers State, Nigeria; a case study of Kaa, B-Dere, and Bodo City. Environ. Monit. Assess. 2016, 188, 9. [CrossRef] [PubMed]

3. Feleke, H.; Medhin, G.; Kloos, H.; Gangathulasi, J.; Asrat, D. Household-stored drinking water quality among households of under-five children with and without acute diarrhea in towns of Wegera District, in North Gondar, Northwest Ethiopia. Environ. Monit. Assess. 2018, 190, 669. [CrossRef]

4. Rabatel, A.; Francou, B.; Soruco, A.; Gomez, J.; Cáceres, B.; Ceballos, J.L.; Basantes, R.; Vuille, M.; Sicart, J.-E.; Huggel, C.; et al. Current state of glaciers in the tropical Andes: A multi-century perspective on glacier evolution and climate change. Cryosphere 2013, 7, 81-102. [CrossRef]

5. Guswa, A.J.; Brauman, K.A.; Brown, C.; Hamel, P.; Keeler, B.L.; Sayre, S.S. Ecosystem services: Challenges and opportunities for hydrologic modeling to support decision making. Water Resour. Res. 2014, 50, 4535-4544. [CrossRef]

6. Custodio, M.; Chanamé, F.; Pizarro, S.; Cruz, D. Quality of the aquatic environment and diversity of benthic macroinvertebrates of high Andean wetlands of the Junín region, Peru. Egypt. J. Aquat. Res. 2018, 44, 195-202. [CrossRef]

7. Chapman, D.V.; Bradley, C.; Gettel, G.M.; Hatvani, I.G.; Hein, T.; Kovács, J.; Liska, I.; Oliver, D.M.; Tanos, P.; Trásy, B.; et al. Developments in water quality monitoring and management in large river catchments using the Danube River as an example. Environ. Sci. Policy 2016, 64, 141-154. [CrossRef]

8. Liu, Y.; Zheng, B.H.; Fu, Q.; Wang, L.J.; Wang, M. The Selection of Monitoring Indicators for River Water Quality Assessment. Procedia Environ. Sci. 2012, 13, 129-139. [CrossRef]

9. Petus, C.; Marieu, V.; Novoa, E.; Chust, G.; Bruneau, N.; Froidefond, J.M. Monitoring spatio-temporal variability of the Adour River turbid plume (Bay of Biscay, France) with MODIS 250-m imagery. Cont. Shelf Res. 2014, 74, 35-49. [CrossRef]

10. Quispe-Coica, F.A.; Fernández, S.; Acharte, L.; Pérez-Foguet, A. Status of water quality for human consumption in high-Andean rural communities: Discrepancies between techniques for identifying trace metals. Multidiscip. Sci. J. 2020, 3, 162-180. [CrossRef]

11. Choque-Quispe, D.; Ligarda-Samanez, C.A.; Solano-Reynoso, A.M.; Ramos-Pacheco, B.S.; Quispe-Quispe, Y.; Choque-Quispe, Y.; Kari-Ferro, A. Water quality index in the high-Andean micro-basin of the Chumbao River, Andahuaylas, Apurímac, Peru. Tecnol. Y Cienc. Agua 2021, 12, 37-73. [CrossRef]

12. Kumar, B.; Mukherjee, D.P. Assessment of human health risk for arsenic, copper, nickel, mercury and zinc in fish collected from tropical wetlands in India. Adv. Life Sci. Technol. 2011, 2, 13-24.

13. Lu, S.Y.; Zhang, H.M.; Sojinu, S.O.; Liu, G.H.; Zhang, J.Q.; Ni, H.G. Trace elements contamination and human health risk assessment in drinking water from Shenzhen, China. Environ. Monit. Assess. 2015, 187, 4220. [CrossRef]

14. Daud, M.K.; Nafees, M.; Ali, S.; Rizwan, M.; Bajwa, R.A.; Shakoor, M.B.; Arshad, M.U.; Chatha, S.A.S.; Deeba, F.; Murad, W.; et al. Drinking water quality status and contamination in Pakistan. BioMed Res. Int. 2017, 2017, 7908183. [CrossRef]

15. Kirschke, S.; Avellán, T.; Bärlund, I.; Bogardi, J.J.; Carvalho, L.; Chapman, D.; Dickens, C.W.S.; Irvine, K.; Lee, S.B.; Mehner, T.; et al. Capacity challenges in water quality monitoring: Understanding the role of human development. Environ. Monit. Assess. 2020, 192, 298. [CrossRef] [PubMed]

16. WHO. Guidelines for Drinking-Water Quality, 4th ed.; Recommendations, 564; World Health Organization: Geneva, Switzerland, 2011. 
17. Adane, M.; Mengistie, B.; Medhin, G.; Kloos, H.; Mulat, W. Piped water supply interruptions and acute diarrhea among under-five children in Addis Ababa slums, Ethiopia: A matched case-control study. PLoS ONE 2017, 12, e0181516. [CrossRef] [PubMed]

18. MINAM. Estándares de Calidad Ambiental (ECA), Decreto Supremo N 004-2017-MINAM-Perú (10 p.); Ministerio del Ambiente: Lima, Perú, 2017.

19. Miranda, M.; Aramburú, A.; Junco, J.; Campos, M. State of the quality of drinking water in households in children under five years in Peru, 2007-2010. Rev. Peru. Med. Exp. Salud Publica 2010, 27, 506-511. [CrossRef]

20. Villena, J.A. Calidad del agua y desarrollo sostenible. Rev. Peru. Med. Exp. Salud Publica 2018, 35, 304-308. [CrossRef]

21. Instituto Nacional de Estadística e Informática Perú: Formas de Acceso al Agua y Saneamiento Básico. Available online: https:/ / www.inei.gob.pe/media/MenuRecursivo/boletines/boletin_agua_nov2019.pdf (accessed on 21 January 2020).

22. APHA. Standard Methods for the Examination of Water and Wastewater, 22nd ed.; American Public Health Association (APHA), American Water Works Association (AWWA) and Water Environment Federation (WEF): Washington, DC, USA, 2012.

23. ISO. Water Quality_Enumeration of Escherichia Coli and Coliform Bacteria_Part 2: Most Probable Number Method—ISO 9308-2:2012; ISO: Geneva, Switzerland, 2014.

24. Singaraja, C.; Chidambaram, S.; Anandhan, P.; Prasanna, M.V.; Thivya, C.; Thilagavathi, R.; Sarathidasan, J. Hydrochemistry of groundwater in a coastal region and its repercussion on quality, a case study-Thoothukudi district, Tamil Nadu, India. Arab. J. Geosci. 2014, 7, 939-950. [CrossRef]

25. Gradilla-Hernández, M.S.; de Anda, J.; Garcia-Gonzalez, A.; Montes, C.Y.; Barrios-Piña, H.; Ruiz-Palomino, P.; Díaz-Vázquez, D. Assessment of the water quality of a subtropical lake using the NSF-WQI and a newly proposed ecosystem specific water quality index. Environ. Monit. Assess. 2020, 192, 296. [CrossRef]

26. de Anda, J.; Gradilla-Hernández, M.S.; Díaz-Torres, O.; de Jesús Díaz-Torres, J.; de la Torre-Castro, L.M. Assessment of heavy metals in the surface sediments and sediment-water interface of Lake Cajititlán, Mexico. Environ. Monit. Assess. 2019, 191, 396. [CrossRef] [PubMed]

27. Chung, P.L.; Chung, C.Y.; Liao, S.W.; Miaw, C.L. Assessment of the school drinking water supply and the water quality in Pingtung County, Taiwan. Environ. Monit. Assess. 2009, 159, 207-216. [CrossRef]

28. Sipahi, F.; Uslu, S. Investigation of the quality and physical-geochemical characteristics of the drinking water in Gümüşhane (Turkey) city central. Arab. J. Geosci. 2016, 9, 600. [CrossRef]

29. Abboud, I.A. Geochemistry and quality of groundwater of the Yarmouk basin aquifer, north Jordan. Environ. Geochem. Health 2018, 40, 1405-1435. [CrossRef] [PubMed]

30. Liu, J.; Feng, J.; Gao, Z.; Wang, M.; Li, G.; Shi, M.; Zhang, H. Hydrochemical characteristics and quality assessment of groundwater for drinking and irrigation purposes in the Futuan River Basin, China. Arab. J. Geosci. 2019, 12, 560. [CrossRef]

31. Mohamed, H.; Brown, J.; Njee, R.M.; Clasen, T.; Malebo, H.M.; Mbuligwe, S. Point-of-use chlorination of turbid water: Results froma field study in Tanzania. J. Water Health 2015, 13, 544-552. [CrossRef] [PubMed]

32. Aksever, F.; Davraz, A.; Bal, Y. Assessment of water quality for drinking and irrigation purposes: A case study of Başköy springs (Ağlasun/Burdur/Turkey). Arab. J. Geosci. 2016, 9, 748. [CrossRef]

33. Islam, M.S.; Ahmed, M.K.; Habibullah-Al-Mamun, M. Determination of heavy metals in fish and vegetables in Bangladesh and health implications. Hum. Ecol. Risk Assess. Int. J. 2015, 21, 986-1006. [CrossRef]

34. Marara, T.; Palamuleni, L. A spatiotemporal analysis of water quality characteristics in the Klip river catchment, South Africa. Environ. Monit. Assess. 2020, 192, 578. [CrossRef] [PubMed]

35. Wong, Y.J.; Shimizu, Y.; He, K.; Sulaiman, N.M.N. Comparison among different ASEAN water quality indices for the assessment of the spatial variation of surface water quality in the Selangor River basin, Malaysia. Environ. Monit. Assess. 2020, 192, 644. [CrossRef]

36. Troudi, N.; Hamzaoui-Azaza, F.; Tzoraki, O.; Melki, F.; Zammouri, M. Assessment of groundwater quality for drinking purpose with special emphasis on salinity and nitrate contamination in the shallow aquifer of Guenniche (Northern Tunisia). Environ. Monit. Assess. 2020, 192, 641. [CrossRef]

37. Narany, T.S.; Ramli, M.F.; Aris, A.Z.; Sulaiman, W.N.A.; Fakharian, K. Spatiotemporal variation of groundwater quality using integrated multivariate statistical and geostatistical approaches in Amol-Babol Plain, Iran. Environ. Monit. Assess. 2014, 186, 5797-5815. [CrossRef]

38. Davraz, A.; Sener, E.; Sener, S. Temporal variations of fluoride concentration in Isparta public water system and health impact assessment (SW-Turkey). Environ. Geol. 2008, 56, 159-170. [CrossRef]

39. Martínez-Acuña, M.I.; Mercado-Reyes, M.; Alegría-Torres, J.A.; Mejía-Saavedra, J.J. Preliminary human health risk assessment of arsenic and fluoride in tap water from Zacatecas, México. Environ. Monit. Assess. 2016, 188, 476. [CrossRef] [PubMed]

40. Chen, J.; Wu, H.; Qian, H.; Gao, Y. Assessing nitrate and fluoride contaminants in drinking water and their health risk of rural residents living in a semiarid region of Northwest China. Expo. Health 2017, 9, 183-195. [CrossRef]

41. González-Horta, C.; Ballinas-Casarrubias, L.; Sánchez-Ramírez, B.; Ishida, M.C.; Barrera-Hernández, A.; Gutiérrez-Torres, D.; Zacarias, O.L.; Saunders, R.J.; Drobná, Z.; Mendez, M.A.; et al. A concurrent exposure to arsenic and fluoride from drinking water in Chihuahua, Mexico. Int. J. Environ. Res. Public Health 2015, 12, 4587-4601. [CrossRef] [PubMed]

42. Gaikwad, S.K.; Kadam, A.R.; Ramgir, R.R.; Kashikar, A.S.; Wagh, V.M.; Kandekar, A.M.; Kamble, K.D. Assessment of the groundwater geochemistry from a part of west coast of India using statistical methods and water quality index. HydroResearch 2020, 3, 48-60. [CrossRef] 
43. Mariño, R. The prevalence of fluorosis in children is associated with naturally occurring water fluoride concentration in Mexico. J. Evid. Based Dent. Pract. 2013, 13, 100-101. [CrossRef]

44. USEPA. National Primary Drinking Water Regulations: Basic Information about Arsenic in Drinking Water; United States Environmental Protection Agency: Washington, DC, USA, 2013.

45. Singh, R.; Venkatesh, A.S.; Syed, T.H.; Reddy, A.G.S.; Kumar, M.; Kurakalva, R.M. Assessment of potentially toxic trace elements contaminationin groundwater resources of the coal mining area of the KorbaCoalfield, Central India. Environ. Earth Sci. 2017, 76, 566. [CrossRef]

46. Al-Othman, A.M.; Al-Othman, Z.A.; El-Desoky, G.E.; Aboul-Soud, M.A.M.; Habila, M.A.; Giesy, J.P. Lead in drinking water and human blood in Riyadh City, Saudi Arabia. Arab. J. Geosci. 2013, 6, 3103-3109. [CrossRef]

47. Othman, F.; Chowdhury, M.S.U.; Wan Jaafar, W.Z.; Faresh, E.M.M.; Shirazi, S.M. Assessing risk and sources of heavy metals in a tropical river basin: A case study of the Selangor River, Malaysia. Pol. J. Environ. Stud. 2018, 27, 1659-1671. [CrossRef]

48. Krishna, P.V.; Jyothirmayi, V.; Rao, K.M. Human health risk assessment of heavy metal accumulation through fish consumption, from Machilipatnam Coast, Andhra Pradesh, India. Int. Res. J. Public Environ. Health 2014, 1, 121-125.

49. Haque, M.M.; Al Attas, H.A.; Hassan, M.A. Health risk assessment of trace elements in drinking water from Najran City, southwestern Saudi Arabia. Arab. J. Geosci. 2016, 9, 464. [CrossRef]

50. Yoshida, T.; Yamauchi, H.; Sun, G.F. Chronic health effects in people exposed to arsenic via the drinking water: Dose-response relationships in review. Toxicol. Appl. Pharmacol. 2004, 198, 243-252. [CrossRef]

51. Schuhmacher-Wolz, U.; Dieter, H.H.; Klein, D.; Schneider, K. Oral exposure to inorganic arsenic: Evaluation of its carcinogenic and non-carcinogenic effects. Crit. Rev. Toxicol. 2009, 39, 271-298. [CrossRef]

52. Cooper, R.G.; Harrison, A.P. The exposure to and health effects of antimony. Indian J. Occup. Environ. Med. 2009, 13, 3-10. [CrossRef] [PubMed]

53. Makris, K.; Andra, S.; Herrick, L.; Christophi, C.; Snyder, S.; Hauser, R. Association of drinking-water source and use characteristics with urinary antimony concentrations. J. Expo. Sci. Environ. Epidemiol. 2012, 23, 120-127. [CrossRef]

54. Liu, J.; Gao, Z.J.; Wang, M.; Li, Y.; Ma, Y.; Shi, M.; Zhang, H. Study on the dynamic characteristics of groundwater in the valley plain of Lhasa City. Environ. Earth Sci. 2018, 77, 646. [CrossRef]

55. Sonkamble, S.; Sahya, A.; Mondal, N.C.; Harikumar, P. Appraisal and evolution of hydrochemical processes from proximity basalt and granite areas of Deccan Volcanic Province (DVP) in India. J. Hydrol. 2012, 438, 181-193. [CrossRef]

56. Caporale, A.G.; Violante, A. Chemical processes affecting the mobility of heavy metals and metalloids in soil environments. Curr. Pollut. Rep. 2016, 2, 15-27. [CrossRef]

57. Rahman, M.A.T.; Saadat, A.H.M.; Islam, M.S.; Al-Mansur, M.A.; Ahmed, S. Groundwater characterization and selection of suitable water type for irrigation in the western region of Bangladesh. Appl. Water Sci. 2017, 7, 233-243. [CrossRef]

58. Wagh, V.; Panaskar, D.; Aamalawar, M.L.; Lolage, Y.P.; Mukate, S.; Narshimma, A. Hydrochemical characterisation and groundwater suitability for drinking and irrigation uses in semiarid region of Nashik, Maharashtra, India. Hydrospatial Anal. 2018, 2, 43-60. [CrossRef]

59. Gonzales, E.; Huamán-Espino, L.; Gutiérrez, C.; Aparco, J.; Pillaca, J. Caracterización de la anemia en menores de cinco años de áreas urbanas de Huancavelica y Ucayali, Perú. Rev. Perú. Medicina. Exp. Salud Publica 2015, 32, 431-439. [CrossRef]

60. Andrés, L.; Boateng, K.; Borja-Vega, C.; Thomas, E.; Andrés, L.; Boateng, K.; Borja-Vega, C.; Thomas, E. Review of In-Situ and Remote Sensing Technologies to Monitor Water and Sanitation Interventions. Water 2018, 10, 756. [CrossRef] 